\title{
Értelmiségi szereprepedések
}

\section{HOZZÁSZÓLÁS PIERRE LÉVY „AZ ÉRTELMISÉG ÚJ FELELŐSSÉGE} A KOMMUNIKÁCIÓ KORÁBAN” CÍMUU ÍRÁSÁHOZ

\section{Szerzői információ:}

Tamás Pál

Az MTA Szociológiai Intézetének igazgatója politológiai szociológiával, technológiapolitikával és transzformációkutatással foglalkozik. Első diplomáit villamosmérnök-informatikusként és közgazdászként szerezte. Vendégoktató és kutató volt amerikai, brit, kanadai, német, osztrák, orosz, lengyel, román, ukrán és más intézetekben, egyetemeken. Újabb projektjei többek között a magyar társadalom evolúciós képességével és a kognitív kapitalizmus kelet-európai meghonosodásával kapcsolatosak.

E-mail: tamas@socio.mta.hu

Így hivatkozzon erre a cikkre:

Tamás Pál. „Értelmiségi szereprepedések”.

Információs Társadalom VIII, 4. szám (2008): 29-32.

— https://dx.doi.org/10.22503/inftars.VIII.2008.4.7

A folyóiratban közölt müvek

a Creative Commons Nevezd meg! - Ne add el! - Így add tovább! 4.0

Nemzetközi Licenc feltételeinek megfelelöen használhatók. 
Tamás Pál

\section{Értelmiségi szereprepedések}

Először azt hittem, a címet félrefordították. Hogy az „értelmiség” terminussal a dolgot esetleg az eredeti közlő intencióival szemben túlpörgették. De nem, Pierre Lévy az eredeti francia közlésben is (Le Monde Diplomatique, 2007/8) „intellectuels”-ról beszél. Egy másik cikke címében olaszul „l’intelligenzá”-ról ír. Tehát akkor szándékosságról van szó. A cikk olvasásából felmerüloó enyhe értetlenségem megmarad. Ha egy mondatban és igazságtalanul kellene összefoglalnom véleményemet Lévy kijelentéseiról, akkor azt mondanám, hogy a technológiai determinizmus olyan gyermekbetegség, amely késóbb is visszajön. S ha már valaki elkapta tízévesen, késóbb ugyan kigyógyult belóle, de megint megkaphatja. Immunrendszerünk ebben az irányban nem múködik.

Komolyra fordítva a szót, problémáimat három blokkban foglalnám össze. Néhány szó a technológiai meghatározottságokról, azután arról, hogy mi történik az értelmiségi szerepekkel és feladatokkal. Végül arról, hogy ugyan áttételeken keresztül, de hogyan változnak az új technológiai mezókben vagy inkább azok hatására bizonyos értelmiségi énképek és lehetôségek.

\section{Technológiai meghatározottságok}

A 60-as években a modern információs társadalommal foglalkozó elméletek elsố hulláma feltételezte, hogy a technológiai változások közvetlenül és kikerülhetetlenül társadalmi-gazdasági változásokat indukáltak. Hogy itt minden majdnem hogy lineáris és azonnali. Megjelennek az új kommunikációs gépek és az emberek - kis ellenállás után vagy a nélkül - elkezdenek azok logikája szerint feladatokat megoldani. Nagyon hamar kiderült, hogy ez persze nincsen így, vagy legalábbis nem magától értetôdóen következik, s akkor két típusválasz született. Az elsóben a vizsgálódó belátja, hogy a technológiai változás az adott szakaszban (tehát mondjuk 1950 és 1980 között) ezen a területen kivételesen gyors, és ez többek között azért is van így, mert az információfeldolgozó gépekkel sikerült egy nagy termelési kultúraváltás generikus technológiáját meglelni. És egyébként is, a hidegháború éveiben ez a technológiai terület a szembenállás kiemelkedően fontos zónájává válik, s ezért akkora forrásokat biztosítanak itt a továbblépéshez katonai területen, hogy ebból, szinte mellesleg, a polgári-gazdasági alkalmazások is ugrottak egy nagyot. És hogy ezt a kivételes gyorsaságú és intenzitású átrendezôdést a szélesebb közvélemény, de még a szakmák zöme is egyszerúen képtelen követni. Az így kialakuló „az ember lemarad” szindrómának ezután további két alosztálya támadt. Az optimisták vagy a jövóbe bolondultak bizonyos permanens technológiai forradalmat vizionáltak. Ebben az adott korszak termelési paradigmaváltását abszolutizálták és végtelenítették idóben is. Mindebból azután levezettek negatív utó- 
piákat is. De még mindig ugyanezen a megközelítésen belül létezett egy másik, realistább változat is. Ennek a szószólói egyfelól azt mondták, hogy a forradalmibb szakaszokat szükségszerúen nyugodtabbak követik, tehát utol lehet érni a technológiát. Másfelól a felhasználó maga is szelektál, és ha valamilyen alkalmazási irányzatokat, feladatokat, lehetôségeket nem kedvel, ha azoktól strukturálisan idegenkedik, akkor azok elóbb vagy utóbb el is fognak halni. Tehát önmagában nem sokat számít, hogy a technológia felajánl egy ilyen lehetőséget, ha az alkalmazói közegek számára ez nem jelent az ő oldalukról, az általuk megoldott feladatok oldaláról kihívást, akkor arra egyszerúen nem fognak reagálni. Nem lesznek partnerei. És az adott irányzat, bármekkora is benne elvben a technikai fantázia, elóbb vagy utóbb elhal.

A második alapvetố megközelítés már ekkor felismeri, hogy a technológia maga is hordoz társadalmi kapcsolatokat, hogy a fejlesztő központokat körülvevő közeg hierarchikus rendje, vágyai, üzleti feladatai és kollektív félelmei maguk is beépülnek a technológiába. Meghatározzák ezek szerkezetét, nyelvét, megoldandó céljait, sốt ezeket technikai rendbe rejtve exportálják is az új alkalmazókhoz. Késóbb azután puhább elméletek jelentek meg, amelyek az alkalmazónak sokkal nagyobb szabadságot hirdettek, s úgy vélték, lehetôségeik sokkal nagyobbak annál, mint ahogy ezt egyébként a szélesedő technológiai kínálat ideológusai állították (egyébként úgy túnik, hogy többszörösen modernizált változatban, de Lévy is ilyen kínálati ideológus). Ebben a szakaszban megjelentek végül a tudástársadalom keresleti ideológusai is, akik már nem hitték, hogy mindabból, amit a technológiai fejlesztés kínál, azonnal és kötelezôen választani kell, hogy létezik valamiféle morális kényszer (amelyet egyébként Lévy itt már cikkének a címében is jelez azzal, hogy „új felelősségról” beszél).

Az itt leírt modell 10-15 éves technológiai ciklusok mellé rendeződik, a keresleti és kínálati, a determinista és a „szabadválasztási” ideológiák ezalatt általában egyszer megfordulnak, és új körben kezdődik minden elölról. Lényegében 3-4 ilyen ciklust az elmúlt majd' 50 évben megéltünk. A magam részéról én itt elvetném az „új felelôsség” kifejezést. Ha céljainak, igényeinek ez felel meg, akkor az alkalmazó gazdasági, kulturális, ideológiai és mentális versenyhelyzetekben a saját céljaira használhatja a technológiát. S ha annak belsó logikáját jobban érti és pontosabban követi, akkor azt hatékonyabban fogja használni. De morális nyomásról szó sem lehet.

\section{Értelmiségi szerep}

Az „értelmiségi” - s itt még nem is utalok a könyvtárnyi irodalomra - abban a formájában, ahogyan a 19. század második felében és a 20. század elsố harmadában összeállt, szintetikus szerep. Annak az entellektüelnek, akiról Lévy a francia címben is beszél, vannak ideológiai feladatai, vannak víziógenerálási feladatai a társadalomirányítás számára és amellett, vagy azzal szembefordulva elláthat mérnöki és kritikai feladatokat is. De nem szakértelmiségi abban az értelemben, ahogy a mérnök, a fizikus, az orvos, a társadalomstatisztikus információt, tudást használ, generál, rendszerez adott részproblémák megértésére és kezelésére. A Lévynél felsorolt feladatok, amelyek egyébként teljesen reálisak, levezethetốk a tudás jelenlegi rosszul kódoltságából és nem kielégítő mértékú integráltságából, szakmai feladatok, de nem feladatok az entellektüel, a vizio- 
nárius értelmiségi számára. Megoldásukra a megrendelést egyébként valószínúleg a politikai vagy gazdasági döntéshozók kezdeményezhetik. Nem hinném azonban, hogy számukra a feladatokat moralizálva kellene megfogalmazni. Mégis ók lehetnek, akik inter- és transzdiszciplináris, komplex problémakezelő szemlélettel valamit csinálhatnak. A tudomány akkor fog ilyen irányokban továbblépni vagy akár vadonatúj fejlesztésekbe is belevágni, ha ók ilyeneket kérnek, sốt finanszíroznak. A döntéshozók egyébként egyes esetekben reagálhatnak a technológiák belső fejlődéséból következő fontos feladatok megoldására. Bizonyára így lehet ez generikus technológiáknál, és az információs technológiák ilyenek. De a megrendeléseket itt bizonyára elsôsorban az érdekek fogják meghatározni. A döntéshozók progresszívnak minősülnek majd, ha felismerik, hogy érdekeik racionalizálhatók, a rációt technológiákkal szolgálhatjuk, és hogy közben ezek a technológiák is hatékonyabbak lesznek, ha kialakításuknál a potenciális felhasználók társadalmi közegére is tekintettel leszünk. Talán csak ennyi az egész. Tehát a szintetikus szerep a döntéshozóé, a megrendelőé és nem a szakértelmiségié. A „felelősség” kifejezés pedig kifejezetten eltávolít a ráció fokozottabb érvényesítésétól.

\section{Új lehetőségek}

Mindezek az áttételek nem zárják ki, hogy az új kommunikációs technológiák valóban - ha nem is közvetlenül - a vizionáló értelmiség számára is kijelölnek új feladatokat. Felsorolásszerúen itt hármat emelnék ki ezek közül: a nemzeti keretek észlelésének viszonylagosságát, az értelmiségi munkamegosztás átalakulását és a tudásszervezés új formáiból következő feladatokat.

Az európai értelmiségi itt érintólegesen bemutatott modellje a nemzetállam keretein belül alakult ki. Ideológiai csomagjait (bár nemzetközi diffúzió itt korábban is létezett) lényegében ezekre a nemzeti piacaira fejlesztette ki. A szeme elốtt lebegó aktorok, mozgalmak, vállalatcsoportok, kormányok, pártok szinte mind kizárólag a nemzetállam keretein belül voltak kigondolhatók. Az információs technológiák nemzetközi hálózatai s az azokból levezethetô politikai kihívások azonban alapvetốn transznacionálisak. Kivételes esetekben a nemzeti tér már elolvadt, sok más ponton még létezik, de kizárólagossága már a múlté. Tulajdonképpen nem a nemzeti és a globális szembeállítása az érdekes, hanem azok a hibrid világok, amelyeket ily módon megélünk. Számos ilyen világban igen fontos a technológiai indíttatás, másokban kevésbé. De ezek nemcsak a szakértelmiségiek szerepeit alakítják át, hanem a vizionáriusokét is. Az, hogy a tudásrendszerek átláthatóságát egymás irányában fokozni kell, szakértelmiségi feladat. Az, hogy egy multikulturális társadalomban az önmaguktól alig érintkező részkultúrák és parciális elitek közé és köré rendszert kell építeni, már az entellektüelek dolga. Itt egyébként megjelennek az értelmiségi munkamegosztás új változatai is.

Végül egy lényegtelen, de nehezen említés nélkül hagyható részlet. Lévy úgy gondolja, vagy legalábbis azt sugallja, hogy az egymással vetélkedó, egymást kizáró szakmai elméletek és ideológiák kavargása, ami ma a társadalomtudományokat jellemzi, azok fejletlenségéról tanúskodik. E területek képviselői nem használják fel vagy rosszul használják azokat a kommunikációs technológiákat, adatbázisokat, módszertani 
lehetôségeket, amelyeket más területek részükre már felkínáltak. Megállapításaikat nem formalizálják eléggé, a struktúrák leírásánál nem élnek a létező technológiai lehetôségekkel stb. Ebben az irányban - az egyik lehetséges irányt választva - természetesen el lehet mozdulni. A szociológia például minden morális nyomástól függetlenül megtanulta és használja a korszerú statisztika eszköztárát. Ez az empirikus kijelentések biztonságát növelte, a társadalom egészének megértését azonban egyáltalán nem. Ott a lehetôségek és a feladatok egészen másból következnek. E területen számos kihívás létezik, s ezek között a technológiai nem a legfontosabb. Ez persze szakértelmiségi dilemma. Tulajdonképpen a kulturális mátrixban a tudás szervezése valóban megváltozik, de számos területen, mindenekelótt azokon, amelyek kisebb-nagyobb hibrid közösségekben az entellektüel víziószolgáltató szerepeihez kapcsolódnának, mindenfajta univerzalisztikus ambíciót én nagy óvatossággal kezelnék. S az értelmiség új felelôsségét elsősorban abban látnám, hogy ne ugorjon be olyan megoldási módoknak és ajánlatoknak, amelyek technológiailag lehet, hogy könnyítettek, de a szükségesnél kevésbé komplexek és a helyi világokhoz kötöttek. 